\title{
Synthetic Versus Biological Mesh-Related Erosion After Laparoscopic Ventral Mesh Rectopexy: A Systematic Review
}

\author{
Andrea Balla, Silvia Quaresima ${ }^{1}$, Sebastian Smolarek ${ }^{2}$, Mostafa Shalaby $^{1}$, Giulia Missori ${ }^{1}$, Pierpaolo Sileri ${ }^{1}$ \\ Department of General Surgery and Surgical Specialties "Paride Stefanini", Sapienza University of Rome, Rome, Italy; ${ }^{1}$ Department of Surgery, \\ Tor Vergata University, Rome, Italy; ${ }^{2}$ Pelvic Oncology Fellow, Abertawe Bro Morgannwg University Health Board, Swansea, UK
}

Purpose: This review reports the incidence of mesh-related erosion after ventral mesh rectopexy to determine whether any difference exists in the erosion rate between synthetic and biological mesh.

Methods: A systematic search of the MEDLINE and the Ovid databases was conducted to identify suitable articles published between 2004 and 2015. The search strategy capture terms were laparoscopic ventral mesh rectopexy, laparoscopic anterior rectopexy, robotic ventral rectopexy, and robotic anterior rectopexy.

Results: Eight studies (3,956 patients) were included in this review. Of those patients, 3,517 patients underwent laparoscopic ventral rectopexy (LVR) using synthetic mesh and 439 using biological mesh. Sixty-six erosions were observed with synthetic mesh (26 rectal, 32 vaginal, 8 recto-vaginal fistulae) and one (perineal erosion) with biological mesh. The synthetic and the biological mesh-related erosion rates were $1.87 \%$ and $0.22 \%$, respectively. The time between rectopexy and diagnosis of mesh erosion ranged from 1.7 to 124 months. No mesh-related mortalities were reported.

Conclusion: The incidence of mesh-related erosion after LVR is low and is more common after the placement of synthetic mesh. The use of biological mesh for LVR seems to be a safer option; however, large, multicenter, randomized, control trials with long follow-ups are required if a definitive answer is to be obtained.

\section{Keywords: Laparoscopic ventral rectopexy; Erosion mesh-related; Synthetic mesh; Biological mesh}

\section{INTRODUCTION}

A rectal prolapse is the circumferential full-thickness protrusion of the rectal wall through the anal orifice [1]. It is a condition most commonly seen in elderly woman, and it is related to particular risks factors such as laxity of the pelvic floor muscles, abnormal fixation of the rectum, or depth of the Douglas pouch $[2,3]$. Several symptoms are associated with a rectal prolapse such as fecal incontinence, constipation, incomplete bowel evacuation,

Received: September 18, 2016 - Accepted: November 20, 2016 Correspondence to: Andrea Balla, M.D.

Department of General Surgery and Surgical Specialties "Paride Stefanini", Sapienza University of Rome, Azienda Policlinico Umberto I, Viale del Policlinico 155, 00161 Rome, Italy

Tel: +39-3394746893, Fax: +39-06-49970549

E-mail: andrea.balla@gmail.com

(C) 2017 The Korean Society of Coloproctology

This is an open-access article distributed under the terms of the Creative Commons Attribution NonCommercial License (http://creativecommons.org/licenses/by-nc/4.0) which permits unrestricted noncommercial use, distribution, and reproduction in any medium, provided the original work is properly cited. bleeding, ulceration, mucus discharge, pain, and incarceration [4]. Perineal and transabdominal approaches have been proposed for the surgical treatment of patients with a rectal prolapse [5]. The abdominal approach is associated with better outcome and lower recurrence rate, but higher mortality, and the recent introduction of a laparoscopic approach has reduced postoperative complications and the length of hospital stay [6]. Laparoscopic rectopexy is the most commonly used transabdominal surgical technique. It can be performed by mobilizing the rectum anteriorly and posteriorly and suturing 2 meshes on the antero-lateral rectal wall (Orr-Loygue technique) [7] or mobilizing only the anterior rectal wall (ventral rectopexy) and fixing the mesh onto both it and the promontorium. This technique was first described in 2004 by D’Hoore et al. [8].

Synthetic mesh is much more widely used than biological mesh during a rectopexy, but no consensus regarding which type of mesh to use has been achieved [6]. Mesh-related pelvic structures erosion after rectopexy has been described in the literature [2], but data on the incidence of erosion based on the mesh type are 
lacking. The aim of this review is to report the incidence of meshrelated erosion after ventral mesh rectopexy performed by using minimally-invasive techniques (laparoscopic and robotic) and to determine whether any difference in the erosion rate exists between synthetic and biological mesh.

\section{METHODS}

A comprehensive systematic search of the literature was conducted in accordance with the PRISMA (Preferred Reporting Items for Systematic Review and Meta-Analysis) guidelines [9]. The MEDLINE (1946 to present) and the Ovid (1980 to present) electronic databases were searched covering the period between January 2004 and November 2015. The start date of review was chosen to be the time when the laparoscopic ventral mesh rectopexy was first described by D'Hoore at al. [8]. The search was carried out using the following terms: "laparoscopic ventral rectopexy," "laparoscopic anterior rectopexy," "robotic ventral rectopexy," and "robotic anterior rectopexy."

Abstracts and conference proceedings were excluded during preliminary screening due to the high risk of incomplete data. The search results were supplemented by a hand search of selected reviews, and the reference lists of all included studies were reviewed to identify potentially eligible studies that had been missed in the initial search. Studies were eligible for inclusion if they were full-text English-language articles and reported on the ventral rectopexy technique with the application of synthetic or biological mesh by using a minimally-invasive approach (laparoscopic or robotic) or were studies that reported synthetic or biological mesh-related rectal, vaginal or pelvic erosion. No restric- tions were applied based on the number of patients in the study or the type of the study. Studies were excluded if they were reviews or meta-analyses, were in a language other than English, employed surgical techniques different from that described by D'Hoore et al. [8], or reported on an open ventral rectopexy; studies that did not report on postoperative complications and eventually studies in which a considerable overlap concerning authors, centers, and patients cohorts existed were also excluded. Due to the limited numbers of papers reported on mesh-related erosion, no restriction based on the quality of the study was used.

Data were independently extracted by 2 reviewers (AB and SQ) who used a dedicated data extraction form. The number, genders, and ages of the patients in each study were extracted, as were the indications for surgery, mesh type, overall postoperative complications, presence of mesh-related erosion, mesh-related mortality, postoperative length of stay (LOS), time between operation and diagnosis of mesh erosion, and length of follow-up. After the titles and the abstracts had been screened, articles that fulfilled the eligibility criteria were identified, and the full text of each publication was reviewed.

For the assessment of the methodological quality of the studies, the Cochrane Collaboration's Tool was used to assess the risk of bias for randomized controlled trials [10], as was the methodological index for nonrandomized studies (MINORS) for nonrandomized studies [11]. For noncomparative studies, a maximum score of 16 could be achieved, and for comparative studies, the maximum score was 24 . All articles that were included in the review were scored independently by 2 authors ( $A B$ and SQ).

Data are presented as frequencies and percentage. Comparative analyses of categorical data were performed using the chi-square
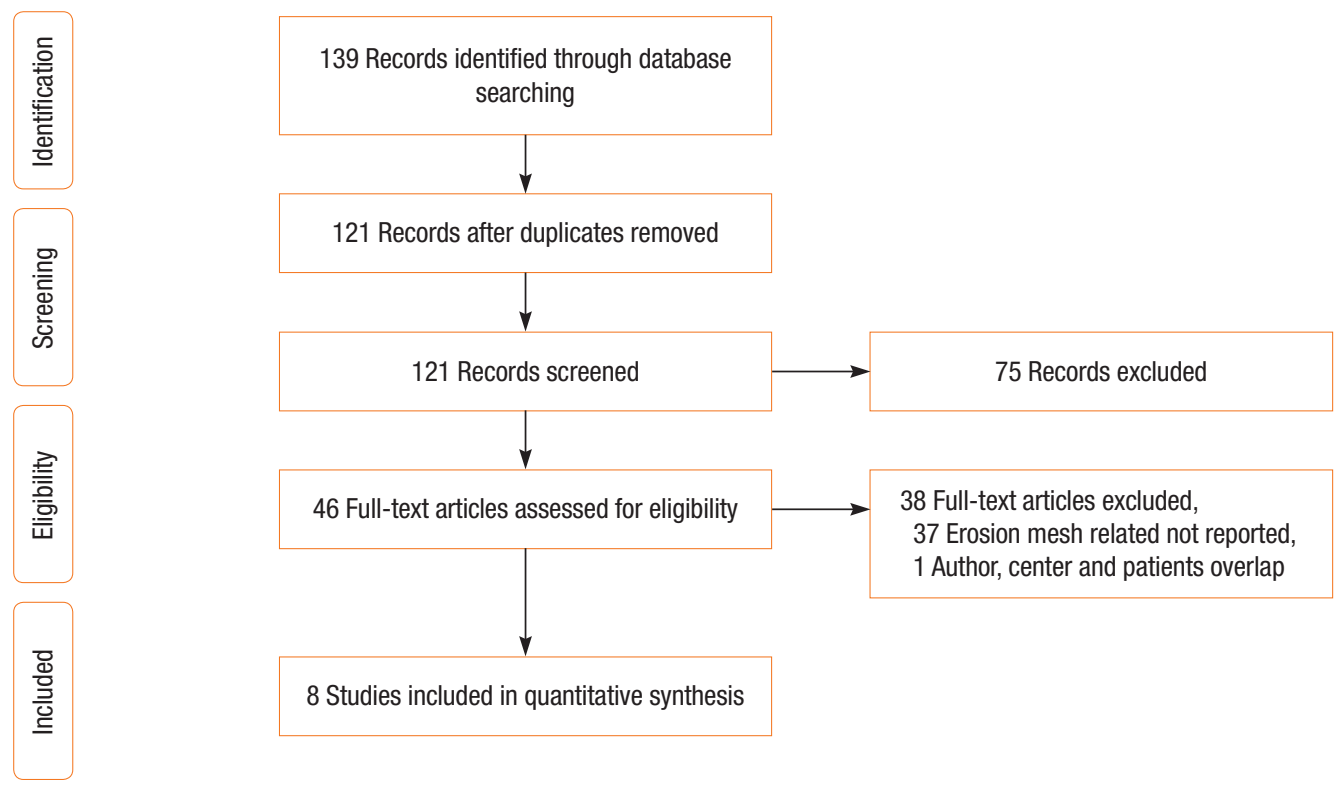

Fig. 1. PRISMA (Preferred Reporting Items for Systematic Review and Meta-Analysis) flow diagram. 
test. The Mann-Whitney U-test was used to compare ordinal data where appropriate. A P-value less than 0.05 was consider statistically significant. All statistical analyses were performed using SAS version 9.1 (SAS Institute, Cary, NC, USA).

\section{RESULTS}

The research identified 139 papers, of which 18 were excluded for overlap between the searches. After the inclusion and exclusion criteria had been applied, another 75 studies were excluded based on title and abstract. The remaining 46 studies were fully analyzed. Thirty-eight of those 46 studies were excluded due surgery other than ventral rectopexy having been performed, postoperative complications not having been reported, or mesh-related erosion having not been observed among the complications; thus, eight studies were deemed eligible for inclusion (Fig. 1) [12-19]. All studies reported synthetic mesh-related erosion [12-19], and 1

Table 2. Number of cases in which was used any type of mesh

\begin{tabular}{lc}
\hline Type of mesh & No. of cases employed (\%) \\
\hline Synthetic Mesh & \\
Polypropylene & $2,085(59.02)$ \\
Polyester & $850(24.16)$ \\
Titanium-coated polypropylene & $160(4.54)$ \\
Synthetic mesh type not specified & $422(11.99)$ \\
Biological mesh & \\
Porcine dermal collagen & $309(70.4)$ \\
Porcine small intestinal submucosa & $130(29.6)$ \\
\hline
\end{tabular}

Table 1. Summary of included studies

\begin{tabular}{|c|c|c|c|c|c|c|c|c|c|c|c|}
\hline Study & $\begin{array}{l}\text { Type of } \\
\text { study }\end{array}$ & $\begin{array}{c}\text { No. } \\
\text { of } \\
\text { patients }\end{array}$ & Sex, M:F & Age (yr) & Mesh-type & $\begin{array}{c}\text { Overall } \\
\text { postoperative } \\
\text { complications, } \\
\mathrm{n}(\%)\end{array}$ & $\begin{array}{l}\text { Mesh- } \\
\text { related } \\
\text { erosions }\end{array}$ & $\begin{array}{l}\text { Mesh- } \\
\text { related } \\
\text { mortality }\end{array}$ & $\begin{array}{l}\text { Hospital } \\
\text { stay (day) }\end{array}$ & $\begin{array}{l}\text { Elapsed time } \\
\text { between } \\
\text { LVR and erosion } \\
\text { diagnosis (mo) }\end{array}$ & $\begin{array}{l}\text { Follow-up } \\
\text { (mo) }\end{array}$ \\
\hline $\begin{array}{l}\text { Wong, } 2011 \\
\text { [12] }\end{array}$ & Prospective & 84 & $0: 84$ & Mean $64 \pm 5$ & Polyester & $3(3.5)$ & 1 Vaginal & 0 & Mean $5 \pm 1$ & NS & $\begin{array}{l}\text { Median } 29 \\
(4-59)\end{array}$ \\
\hline $\begin{array}{l}\text { Faucheron, } \\
2012 \text { [13] }\end{array}$ & Prospective & 175 & $17: 158$ & $\begin{array}{l}\text { Mean } 58 \\
(16-94)\end{array}$ & Polyester & $9(5.1)$ & 1 Rectal & 0 & $\begin{array}{l}\text { Median } \\
2.2(1-12)\end{array}$ & 9 & $\begin{array}{l}\text { Median } 74 \\
(24-181)\end{array}$ \\
\hline $\begin{array}{l}\text { Tranchart, } \\
2013 \text { [14] }\end{array}$ & Prospective & 312 & $39: 273$ & $\begin{array}{l}\text { Median } 60 \\
(18-90)\end{array}$ & Polyester & NS & 6 Rectal & 0 & $\begin{array}{l}\text { Median } \\
5(3-8)^{\mathrm{a}}\end{array}$ & $\begin{array}{l}\text { Median } 53 \\
(4-124)\end{array}$ & $\begin{array}{l}\text { Median 20,5 } \\
(1-40)^{\mathrm{a}}\end{array}$ \\
\hline $\begin{array}{l}\text { Gosselink, } \\
2013 \text { [15] }\end{array}$ & Prospective & 72 & $5: 67$ & NS & Polypropylene & $9(12.5)$ & 1 Vaginal & 0 & $\begin{array}{l}\text { Median } \\
1(1-3)\end{array}$ & 5 & Minimum 12 \\
\hline \multirow[t]{3}{*}{$\begin{array}{l}\text { Randall, } \\
2014 \text { [16] }\end{array}$} & Prospective & $190^{b}$ & $24: 166$ & $\begin{array}{l}\text { Median } 69 \\
(18-93)\end{array}$ & Polypropylene & $22(11.5)$ & 4 Vaginal & 0 & $\begin{array}{l}\text { Median } \\
2.2(0-45)\end{array}$ & NS & $\begin{array}{l}\text { Median } 29 \\
(1-196)\end{array}$ \\
\hline & & & & & & & 2 Rectal & & & & \\
\hline & & & & & & & $1 \mathrm{RVF}$ & & & & \\
\hline \multirow[t]{2}{*}{$\begin{array}{l}\text { Consten, } \\
2015 \text { [17] }\end{array}$} & Retrospective & $919^{c}$ & $50: 869$ & Mean 55.8 & Polypropylene 498 & $114(12.4)$ & 7 Vaginal & 0 & $\begin{array}{l}\text { Median } \\
4(1-30)\end{array}$ & $\begin{array}{l}\text { Median } 8.9 \\
(1.7-47.9)\end{array}$ & $\begin{array}{l}\text { Median } 33.9 \\
(0.4-143.6)\end{array}$ \\
\hline & & & & & $\begin{array}{l}\text { Prolene - Polyester } \\
421\end{array}$ & & & & & & \\
\hline $\begin{array}{l}\text { Adeyemo, } \\
2014 \text { [18] }\end{array}$ & Case report & 1 & $0: 1$ & 63 & Synthetic (NS) & 1 & 1 Rectal & 0 & NS & 24 & NS \\
\hline \multirow[t]{5}{*}{$\begin{array}{l}\text { Evans, } 2015 \\
{[19]}\end{array}$} & Prospective & 1,764 & $152: 2,051$ & $\begin{array}{l}\text { Median } \\
59 \pm 16 \\
(15-82)\end{array}$ & $\begin{array}{l}\text { Polypropylene } \\
1,325\end{array}$ & $883(40)$ & 19 Vaginal & 0 & NS & $\begin{array}{l}\text { Median } 27 \pm 18 \\
(2-78)\end{array}$ & $\begin{array}{l}\text { Median } 38 \\
(0-162)\end{array}$ \\
\hline & & & & & $\begin{array}{l}\text { TC Polypropylene } \\
160\end{array}$ & & 16 Rectal & & & & \\
\hline & & & & & Polyester 279 & & 7 RVF & & & & \\
\hline & & 439 & & & PDC 309 & & 1 Perineal & & & $\begin{array}{l}\text { Median } 2.5 \pm 6.1 \\
(2-14)\end{array}$ & $\begin{array}{l}\text { Median } 26 \\
(0-68)\end{array}$ \\
\hline & & & & & PSIS 130 & & & & & & \\
\hline
\end{tabular}

LVR, laparoscopic ventral rectopexy; NS, not specified; RVF, recto-vaginal fistula; TC, titanium-coated; PDC, porcine dermal collagen; PSIS, porcine small intestinal submucosa.

aAbout only patients with mesh-related erosion. ${ }^{\mathrm{D} T}$ Twenty-two patients underwent additional procedures. ${ }^{\circ}$ One hundred six patients underwent additional procedures. 
Table 3. The MINORS criteria and scores applied to nonrandomized studies included in the review

\begin{tabular}{|c|c|c|c|c|c|c|c|c|c|c|c|c|c|}
\hline \multirow[b]{2}{*}{ Study } & \multirow{2}{*}{$\begin{array}{l}\text { A clearly } \\
\text { stated } \\
\text { aim }\end{array}$} & \multirow{2}{*}{$\begin{array}{l}\text { Inclusion of } \\
\text { consecutive } \\
\text { patients }\end{array}$} & \multirow{2}{*}{$\begin{array}{l}\text { Prospective } \\
\text { collection } \\
\text { of data }\end{array}$} & \multirow{2}{*}{$\begin{array}{l}\text { Endpoint } \\
\text { appropriate } \\
\text { to the aim } \\
\text { of the } \\
\text { study }\end{array}$} & \multirow{2}{*}{$\begin{array}{l}\text { Unbiased } \\
\text { assessment } \\
\text { of the study } \\
\text { endpoint }\end{array}$} & \multirow{2}{*}{$\begin{array}{l}\text { Follow-up } \\
\text { period } \\
\text { appropriate } \\
\text { to the aim } \\
\text { of the } \\
\text { study }\end{array}$} & \multirow{2}{*}{$\begin{array}{l}\text { Loss of } \\
\text { follow up } \\
\text { less than } \\
5 \%\end{array}$} & \multirow{2}{*}{$\begin{array}{l}\text { Prospective } \\
\text { calculation } \\
\text { of the } \\
\text { study size }\end{array}$} & \multicolumn{4}{|c|}{ Additional criteria for comparative studies } & \multirow[b]{2}{*}{ Total } \\
\hline & & & & & & & & & $\begin{array}{l}\text { An adequate } \\
\text { control group }\end{array}$ & $\begin{array}{c}\text { Contemporary } \\
\text { group }\end{array}$ & $\begin{array}{l}\text { Baseline } \\
\text { equivalent } \\
\text { of groups }\end{array}$ & $\begin{array}{c}\text { Adequate } \\
\text { statistical } \\
\text { analysis }\end{array}$ & \\
\hline $\begin{array}{l}\text { Wong, } \\
2011 \text { [12] }\end{array}$ & 1 & 2 & 2 & 2 & 1 & 2 & 2 & 0 & NA & NA & NA & NA & 12 \\
\hline $\begin{array}{l}\text { Tranchart, } \\
2013[14]\end{array}$ & 2 & 2 & 0 & 2 & 1 & 2 & 0 & 0 & NA & NA & NA & NA & 9 \\
\hline $\begin{array}{l}\text { Gosselink, } \\
2013 \text { [15] }\end{array}$ & 2 & 2 & 2 & 2 & 2 & 2 & 2 & 2 & NA & NA & NA & NA & 16 \\
\hline $\begin{array}{l}\text { Randall, } \\
\text { 2014[16] }\end{array}$ & 1 & 2 & 2 & 2 & 1 & 2 & 1 & 0 & NA & NA & NA & NA & 11 \\
\hline $\begin{array}{l}\text { Evans, } \\
2015 \text { [19] }\end{array}$ & 2 & 2 & 2 & 2 & 2 & 2 & 2 & 0 & 0 & 2 & 2 & 2 & 18 \\
\hline
\end{tabular}

The items are scored 0 (not reported), 1 (reported but inadequate) or 2 (reported but adequate). The global ideal score is 16 for noncomparative studies and 24 for comparative studies.

MINORS, methodological index for nonrandomized studies; NA, not applicable.

Table 4. Erosion mesh-related based on mesh type

\begin{tabular}{lccc}
\hline Erosions mesh-related & $\begin{array}{c}\text { Synthetic mesh, } \\
\mathrm{n}(\%)\end{array}$ & $\begin{array}{c}\text { Biological mesh, } \\
\mathrm{n}(\%)\end{array}$ & P-value \\
\hline Rectal & $26(0.73)$ & - & \\
Vaginal & $32(0.90)$ & - & \\
Perineal & - & $1(0.22)$ & \\
Recto-vaginal fistula (RVF) & $8(0.22)$ & - & \\
Total & $66(1.87)$ & $1(0.22)$ & 0.012 \\
\hline
\end{tabular}

study [19] reported both synthetic and biological mesh-related erosion (Table 1). Six studies were prospective, none of which was a randomized clinical trial $[12-16,19], 1$ study was retrospective [17], and 1 study was a case report (Table 1) [18].

The total number of patients were 3,956 (287 male and 3,669 female patients), of which 3,517 underwent LVR using synthetic mesh and 439 using biological mesh (Tables 1,2). The indications for LVR were an external rectal prolapse, an internal rectal prolapse, and a rectocele (Table 1). The numbers of patients, their genders, their ages, the mesh types, the overall postoperative complications, the presence of mesh-related erosion, mesh-related mortality, the LOSs, the times between ventral rectopexy and mesh erosion, and the lengths of follow-up are reported in Table 1. The MINORS scores for all the studies are displayed in Table 3.

Polypropylene mesh was used in 2,085 cases, polyester in 850 cases, titanium-coated polypropylene in 160 cases, porcine der- mal collagen in 309 cases, and porcine small-intestinal submucosa in 130 cases $[12-17,19]$. In 1 study, the synthetic mesh type was not specified [18], and in the study of Consten et al. [17], 421 patients underwent LVR with placement of a prolene or a polyester mesh, but the exact number for each mesh type was not specified (Table 2). Of the 3,956 patients, 1,041 (26.2\%) experienced postoperative complications, 67 (1.7\%) of which were mesh-related erosion. Of the 67 mesh-related erosions, 66 were related to synthetic mesh ( 26 rectal, 32 vaginal, 8 recto-vaginal fistulae), and 1 was erosion associated with biological mesh (perineal erosion) (Table 4). All observed erosions were treated surgically (transvaginally, transanally, or laparoscopically) and were classified as grade III-b according to Clavien-Dindo classification [20]. The synthetic and the biological mesh-related erosion rates were $1.87 \%$ and $0.22 \%$, respectively $(\mathrm{P}=0.012$ ) (odds ratio, 8.38 ; $95 \%$ confidence interval, 1.16-60.5). The time between ventral rectopexy and diagnosis of mesh erosion ranged between 1.7 to 124 months (Table 1). No mesh-related mortalities were reported.

\section{DISCUSSION}

A total number of 3,956 patients from 8 different studies [12-19] that reported on mesh erosion after LVR were included in this systematic review. Only $11.9 \%$ of the patients had biological mesh implemented. This frequency is similar to those observed by other authors and was seen to have been stable with time [2]. The reported rate of mesh-related erosion is low in both groups; how- 
ever, it is significantly lower in the biological-mesh group. This is even more important when we take into account that most of the included review studies had short median follow-up periods that ranged from 12 to 74 months. A possibly exists that with a longer observation period, the difference will be even more significant. The aim of this review was to investigate the incidence of meshrelated erosion after LVR. During the literature search, the authors found that randomized control trials were lacking and that available studies had a high risk of bias. Due to these findings, as well as the nonuniformity of the ways in which the data had been reported, the authors were unable to conduct a meta-analysis.

Based on the present study, biological mesh seems to have fewer postoperative complications, especially mesh-related erosion. A biological implant, however, is more difficult to suture to the sacral promontory, thus requiring more advanced laparoscopic skills [21]. Biological mesh is also more expensive and can significantly increase the cost of the operation [21]. On the other hand, the use of biological mesh can reduce the costs of treatment by reducing the postoperative complications rate [2,22]. This is even more important when cases with high risk of fistula creation, such as those with Crohn disease, diverticular disease, previous pelvic irradiation, and diabetes and smoker patients $[2,22]$, are taken into account. We must emphasize that mesh-related erosion is a severe complication that is classified as grade III-b according to Clavien-Dindo classification [20] and almost always requires surgical treatment. This treatment of mesh-related erosion may itself cause significant functional sequelae in cases of low anterior resection, with a worsening of the patients' quality of life, especially in cases involving stoma creation [23-27].

The main limitation of the present review is the poor quality of the data available in the literature. Few studies have reported mesh-related erosions. Moreover, due to the low percentage of mesh-related erosions, the authors were not able to apply search restrictions based on the number of patients in the study and the quality of the study. Most studies included in this review had a high risk of bias.

In conclusion, the present review demonstrates that mesh-related erosion after LVR is more frequent after synthetic mesh placement, even though the reported incidence rate for both synthetic and biological meshes is low (synthetic, 1.87\%; biological, $0.22 \%$ ). The available data are, however, accompanied by a high risk of bias. In addition, the follow-up period is short, and no randomized control trials are reported. Therefore, multicenter, randomized, control trials with long follow-up period are needed to determine which mesh is associated with higher risk of erosion and postoperative complications.

\section{CONFLICT OF INTEREST}

No potential conflict of interest relevant to this article was reported.

\section{REFERENCES}

1. Jones OM, Cunningham C, Lindsey I. The assessment and management of rectal prolapse, rectal intussusception, rectocoele, and enterocoele in adults. BMJ 2011;342:c7099.

2. Smart NJ, Pathak S, Boorman P, Daniels IR. Synthetic or biological mesh use in laparoscopic ventral mesh rectopexy--a systematic review. Colorectal Dis 2013;15:650-4.

3. Madiba TE, Baig MK, Wexner SD. Surgical management of rectal prolapse. Arch Surg 2005;140:63-73.

4. Samaranayake CB, Luo C, Plank AW, Merrie AE, Plank LD, Bissett IP. Systematic review on ventral rectopexy for rectal prolapse and intussusception. Colorectal Dis 2010;12:504-12.

5. Tou S, Brown SR, Malik AI, Nelson RL. Surgery for complete rectal prolapse in adults. Cochrane Database Syst Rev 2008;(4): CD001758.

6. Ahmad M, Sileri P, Franceschilli L, Mercer-Jones M. The role of biologics in pelvic floor surgery. Colorectal Dis 2012;14 Suppl 3:19-23.

7. Loygue J, Nordlinger B, Cunci O, Malafosse M, Huguet C, Parc R. Rectopexy to the promontory for the treatment of rectal prolapse. Report of 257 cases. Dis Colon Rectum 1984;27:356-9.

8. D’Hoore A, Cadoni R, Penninckx F. Long-term outcome of laparoscopic ventral rectopexy for total rectal prolapse. Br J Surg 2004;91:1500-5.

9. Moher D, Liberati A, Tetzlaff J, Altman DG; PRISMA Group. Preferred reporting items for systematic reviews and meta-analyses: the PRISMA statement. Int J Surg 2010;8:336-41.

10. Higgins JP, Altman DG, Stone JA. Assessing risk of bias in included studies. In: Higgins JP, Green S, editors. Cochrane handbook for systematic reviews of interventions. 2015 Version 5.1.0, The Cochrane Collaboration; 2011 [uptated 2011 Mar]. Available from: www.cochrane-handbook.org.

11. Slim K, Nini E, Forestier D, Kwiatkowski F, Panis Y, Chipponi J. Methodological index for non-randomized studies (minors): development and validation of a new instrument. ANZ J Surg 2003; 73:712-6.

12. Wong M, Meurette G, Abet E, Podevin J, Lehur PA. Safety and efficacy of laparoscopic ventral mesh rectopexy for complex rectocele. Colorectal Dis 2011;13:1019-23.

13. Faucheron JL, Voirin D, Riboud R, Waroquet PA, Noel J. Laparoscopic anterior rectopexy to the promontory for full-thickness rectal prolapse in 175 consecutive patients: short- and long-term follow-up. Dis Colon Rectum 2012;55:660-5.

14. Tranchart H, Valverde A, Goasguen N, Gravié JF, Mosnier H. Conservative treatment of intrarectal mesh migration after ventral laparoscopic rectopexy for rectal prolapse. Int J Colorectal Dis 2013;28:1563-6.

15. Gosselink MP, Adusumilli S, Gorissen KJ, Fourie S, Tuynman JB, Jones OM, et al. Laparoscopic ventral rectopexy for fecal incontinence associated with high-grade internal rectal prolapse. Dis Colon Rectum 2013;56:1409-14. 
16. Randall J, Smyth E, McCarthy K, Dixon AR. Outcome of laparoscopic ventral mesh rectopexy for external rectal prolapse. Colorectal Dis 2014;16:914-9.

17. Consten EC, van Iersel JJ, Verheijen PM, Broeders IA, Wolthuis AM, D’Hoore A. long-term outcome after laparoscopic ventral mesh rectopexy: an observational study of 919 consecutive patients. Ann Surg 2015;262:742-7.

18. Adeyemo D. Mesh fistulation into the rectum after laparoscopic ventral mesh rectopexy. Int J Surg Case Rep 2014;5:152-4.

19. Evans C, Stevenson AR, Sileri P, Mercer-Jones MA, Dixon AR, Cunningham $\mathrm{C}$, et al. A multicenter collaboration to assess the safety of laparoscopic ventral rectopexy. Dis Colon Rectum 2015; 58:799-807.

20. Clavien PA, Barkun J, de Oliveira ML, Vauthey JN, Dindo D, Schulick RD, et al. The Clavien-Dindo classification of surgical complications: five-year experience. Ann Surg 2009;250:187-96.

21. Gouvas N, Georgiou PA, Agalianos C, Tan E, Tekkis P, Dervenis C, et al. Ventral colporectopexy for overt rectal prolapse and obstructed defaecation syndrome: a systematic review. Colorectal Dis 2015; 17:034-46.

22. Brown RA, Ellis CN. The role of synthetic and biologic materials in the treatment of pelvic organ prolapse. Clin Colon Rectal Surg 2014;27:182-90.

23. Rasmussen OO, Petersen IK, Christiansen J. Anorectal function following low anterior resection. Colorectal Dis 2003;5:258-61.

24. Camilleri-Brennan J, Steele RJ. Objective assessment of morbidity and quality of life after surgery for low rectal cancer. Colorectal Dis 2002;4:61-6.

25. Lezoche E, Paganini AM, Fabiani B, Balla A, Vestri A, Pescatori L, et al. Quality-of-life impairment after endoluminal locoregional resection and laparoscopic total mesorectal excision. Surg Endosc 2014;28:227-34.

26. D’Ambrosio G, Paganini AM, Balla A, Quaresima S, Ursi P, Bruzzone $\mathrm{P}$, et al. Quality of life in non-early rectal cancer treated by neoadjuvant radio-chemotherapy and endoluminal loco-regional resection (ELRR) by transanal endoscopic microsurgery (TEM) versus laparoscopic total mesorectal excision. Surg Endosc 2016; 30:504-11.

27. D’Ambrosio G, Balla A, Mattei F, Quaresima S, De Laurentis F, Paganini AM. Quality of life after endoluminal loco-regional resection (ELRR) by transanal endoscopic microsurgery (TEM). Ann Ital Chir 2015;86:56-60. 